\title{
TORN BETWEEN PATRIOTIC, CIVIC AND DISCIPLINARY ASPIRATIONS. EVOLVING FACES OF BELGIAN AND FLEMISH HISTORY EDUCATION, FROM 1830 TO THE FUTURE
}

\begin{abstract}
History education worldwide faces competing, rival visions and even contrasting expectations. Those expectations can be clustered in three main groups, each pursuing a different main goal for and a different approach towards studying the past: 'nation-building and social cohesion', 'democratic participation and civic behavior', and 'disciplinary understanding'. This contribution examines how secondary school history education in Belgium (since its establishment in 1830) has been given shape, and how its main goals have evolved. Belgium (and later on Flanders) serves as an interesting case study, as the country testifies to a difficult, contested past, has evolved into a nation-state in decline, and is increasingly characterized by intercontinental immigration. Using the three clusters of rival expectations as an analytical framework, it is analyzed what the consecutive main goals for the school subject of history have been, which changes occurred throughout the past two centuries and why, and what have been the effects of these different types of history education on young people. The analysis allows to discern three main stages in the history of history education in Belgium/Flanders. For all three, the main goals are explained, and their effects examined. This contribution concludes with critically discussing the different aims, and, while reporting on the current reform of the school subject of history in Flanders, setting a fourth aim to the fore.
\end{abstract}

Key words: history education; Belgium; nation-building; democratic participation; global citizenship; identity-building; historical consciousness; historical thinking
KAREL VAN NIEUWENHUYSE

University of Leuven, Leuven

E-mail: karel.vannieuwenhuyse@kuleuven.be

CITATION: Van Nieuwenhuyse, K. (2018).

Torn Between Patriotic, Civic and Disciplinary Aspirations. Evolving Faces of Belgian and Flemish History Education, from 1830 to the Future.

Sprawy Narodowościowe. Seria nowa, 2018(50). https://doi.org/10.11649/sn.1634

This work was supported by the author's own resources. No competing interests have been declared.

This is an Open Access article distributed under the terms of the Creative Commons Attribution 3.0 PL License (creativecommons.org/licenses/by/3.0/pl/), which permits redistribution, commercial and non-commercial, provided that the article is properly cited. (C) The Author(s) 2018.

Publisher: Institute of Slavic Studies, Polish Academy of Sciences 


\section{ROZZIEW POMIĘDZY ASPIRACJAMI PATRIOTYCZNYMI, OBYWATELSKIMI I ZROZUMIENIEM DYSCYPLINY. EWOLUCJA OBLICZA NAUCZANIA HISTORII W SZKOŁACH BELGII I FLANDRII OD 1830 ROKU I JEGO PRZYSZŁOŚĆ}

\section{Streszczenie}

Na całym świecie nauczanie historii napotyka konkurujące i rywalizujące ze sobą wyobrażenia, a nawet rodzi sprzeczne oczekiwania. Oczekiwania owe można ująć w trzy kompleksy zasadniczych zagadnień, przy czym każdy z nich ma inny główny cel studiowania przeszłości i inaczej do niego podchodzi; są to: „budowanie narodu i spójność społeczna”, „demokratyczna partycypacja i postawy obywatelskie" oraz "rozumienie dyscypliny". Artykuł omawia, w jaki sposób kształtowało się nauczanie historii w szkołach średnich w Belgii (od jej powstania w 1830 roku) i jak ewoluowały jego główne cele. Belgia (a później Flandria) służy jako interesujący przypadek badawczy, gdyż kraj ten doświadczył trudnej, kontestowanej przeszłości, stał się państwem jednonarodowym w upadku i coraz bardziej właściwa mu jest międzykontynentalna imigracja. Wykorzystując wspomniane wyżej trzy kompleksy złożonych oczekiwań jako analityczne ramy badawcze, autor analizuje najistotniejsze zadania, które stoją przed przedmiotem szkolnym historia, następnie omawia zmiany, które zaszły w tym zakresie w minionych dwóch stuleciach i wyjaśnia ich przyczyny, a wreszcie docieka, jaki wpływ odmienne rodzaje nauczania historii wywarły na młodych ludzi. Analiza pozwala wyróżnić trzy zasadnicze etapy w dziejach nauczania historii w Belgii / Flandrii. Autor objaśnia, jakie główne cele stały przed wszystkimi trzema grupami i jakie przyniosły efekty. Artykuł zamyka krytyczna ocena omawianych celów oraz przedstawienie aktualnie mającej miejsce reformy przedmiotu szkolnego historia we Flandrii, a na końcu wskazanie czwartego celu: edukacji na przyszłość. [Trans. by Jacek Serwański]

Słowa kluczowe: historia nauczania; Belgia; budowanie narodu; partycypacja demokratyczna; globalne obywatelstwo; kształtowanie tożsamości świadomość historyczna; myślenie historyczne

$\mathrm{H}$ istory education worldwide faces competing visions and even contrasting expectations. Those expectations can be clustered in three main groups, each pursuing a different main goal for and a different approach towards studying the past. A first cluster expects history education to contribute to nation-building and social cohesion, and to the fostering of a national identity (Carretero, 2011). Particularly national history is emphasized, and the subject of history is taught in a very teacher-centered, lecturing way. In a second cluster, transnational (sometimes even global) citizenship and democratic civic participation are put to the fore as main aims (Arthur, Davies, Wrenn, Haydn, \& Kerr, 2001). History education is expected to bring young people to good civic and democratic behavior, and to train them in the critical handling of information. Here, teaching history is student-centered, leaving a lot of space for Socratic dialogue, individual and group work, classroom debates and inquiry learning. A third cluster considers a disciplinary understanding as main goal. This is educationally translated into the fostering of historical thinking (Seixas \& Morton, 2013). As thinking historically is rightfully considered an 'unnatural act' (Wineburg, 2001), its development can be achieved both via guided instruction and/or student-centered, activating methods.

Those three clusters only have to a certain (little) extent common ground, as the graph below shows. The clusters 'nation-building and social cohesion' and 'democratic participation and civic behavior' can be considered as two sides of the same coin. Both of them orient history education towards supporting certain identity construction processes and the transmission of values. In so doing, they do not solely rely on academic historiographi- 
cal representations of the past, yet include social representations and historical myths within collective memory as well (Van Nieuwenhuyse \& Wils, 2012). Both clusters hence testify to the fostering of a rather naïve historical consciousness. The clusters 'nationbuilding and social cohesion' and 'disciplinary understanding' share a large interest in the past. They both develop a form of historical consciousness, be it that the first one fosters a rather naïve historical consciousness, the second a critical historical consciousness. The clusters 'democratic participation and civic behavior' and 'disciplinary understanding' have in common that they both aim for critical thinking, and pay attention to diversity, interpretation and inquiry learning; both also develop a form of historical consciousness, be it again a different one (naïve versus critical). This makes clear that the cluster 'disciplinary understanding' is not so much another side of the same coin, yet rather another coin, in which historical thinking, reflection and critical deconstruction of historical representations occupy center stage (Seixas, 2017).

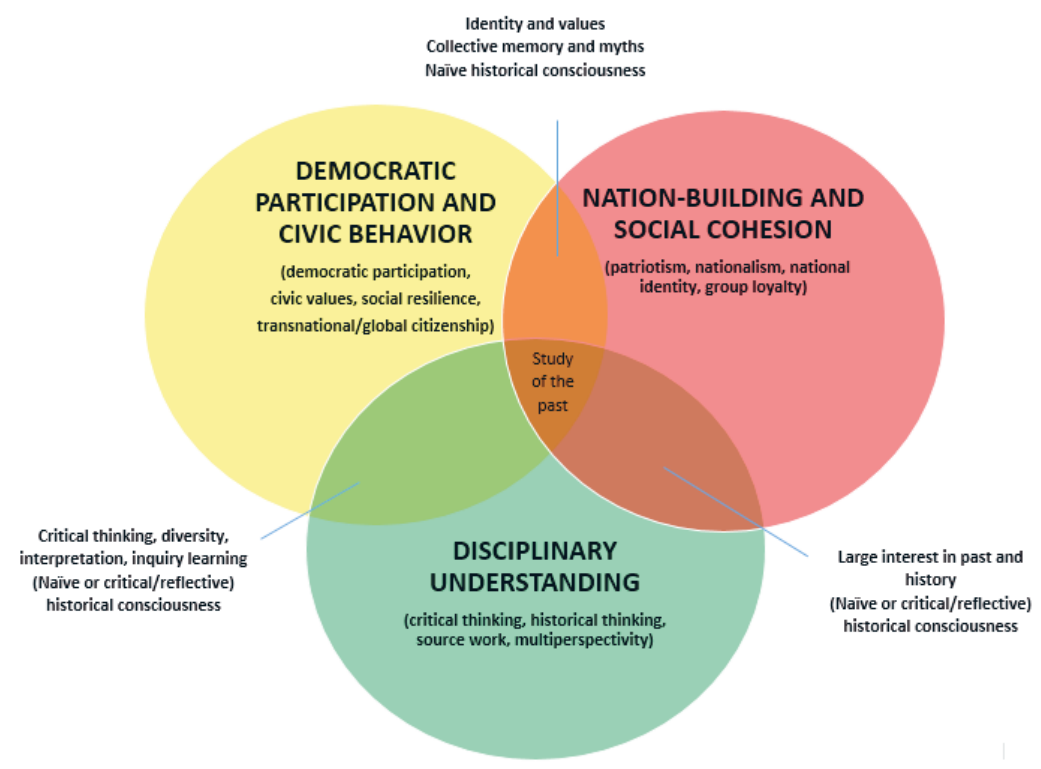

Graph 1: Three clusters of expectations towards history education.

In debates addressing (aims for) history education, Belgium (and later on Flanders) is an interesting case study, as the country testifies to a difficult, contested past, and has evolved into a nation-state in decline. Ever since its formal establishment as an independent state in 1830, Belgium and its society has been divided by ideological (between catholics and non-catholics), socio-economic (between labourers and capitalists), and communitarian/linguistic (between Flemings and francophones) tensions (Witte, Craeybeckx, \& Meynen, 2009). Belgium, being a young nation-state, nevertheless tried to build a national identity and to foster social cohesion among its citizens. After the First, and certainly after the Second World War, the tensions between population groups, however, grew, resulting in a gradual institutional process of regionalization. Furthermore, throughout the $20^{\text {th }}$ century, Belgium increasingly became a country characterized by immigration (with migrants first coming from Southern and Eastern European states, later on also from Turkey, Northern Africa, and other parts of the world). 
The question then arises how, in these changing and complex contexts, secondary school history education in Belgium (since its establishment in 1830) has been given shape, and how its main goals have evolved. This contribution uses the abovementioned model of rival expectations as an analytical framework to examine this. What have been consecutive main goals for the school subject of history? Which changes occurred, and why? And what have been the effects of these different types of history education on young people? In general, three main stages can be discerned in the history of history education in Belgium/Flanders. In the next parts, each of them will be addressed; afterwards, the current reform of the school subject of history, is discussed.

\section{BELGIAN HISTORY EDUCATION UNTIL THE 1950S: MAINLY CHARACTERIZED BY IMPARTING PATRIOTISM}

In the $19^{\text {th }}$ century, Belgium, like in many West European countries, witnessed a broad cultural process of canonisation of the national past. The government considered history education as a natural component of the formation of patriotism, of social cohesion and of national identity (Van Nieuwenhuyse \& Wils, 2015; Wils, 2009). Patriotism was pursued in history education, among others, by instilling a master narrative and shared knowledge of the national past. Furthermore, young people were provided with exempla to follow, of great and virtuous men from the past professing the 'right' values and virtues (Wils, 2009). History, and particularly the national past, provided guidelines for present and future (Historia magistra vitae est). This main aim left no space for pedagogical innovation. History education was very teacher-centred and did not testify to active teaching methods; students only had to listen, absorb and repeat.

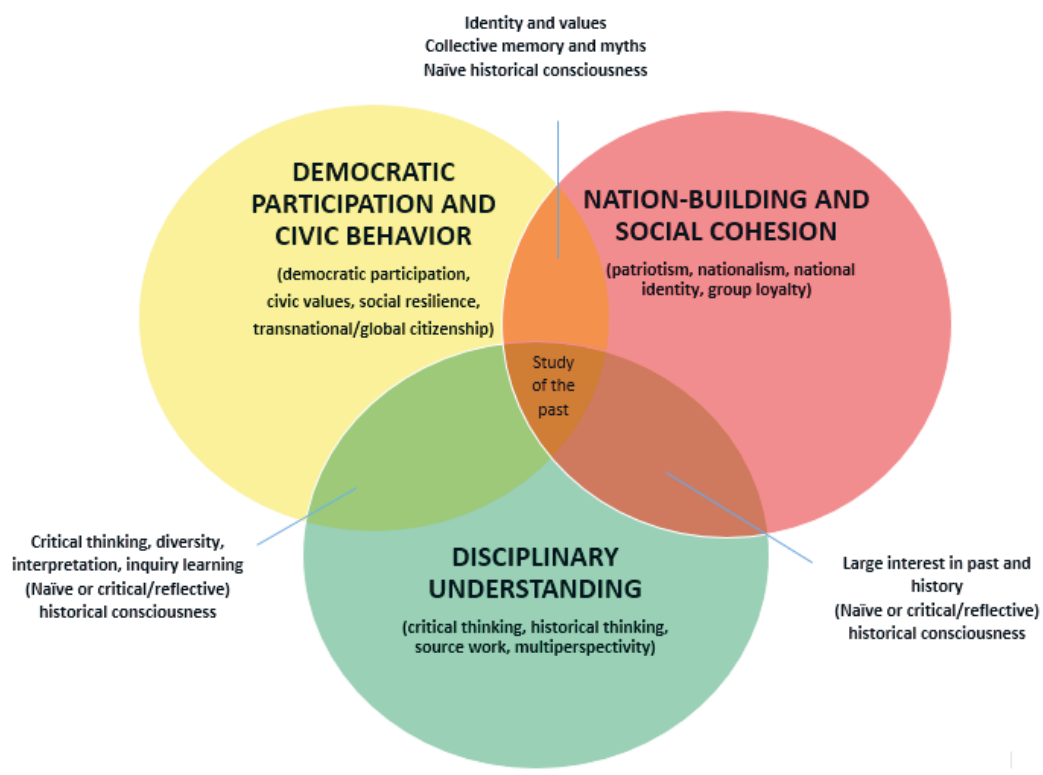

Graph 2: Belgian history education until the 1950s situated in the three clusters. 
Compared to many other European countries, the nationalisation of history education has never been radical in Belgium however. Although national history enjoyed a privileged position, and was taught separately from 'general' (mainly European) history, the teaching of the national past never occupied more than a third of the overall history curriculum. After the First World War, as the danger of exaggerated chauvinism was pointed out internationally, a plea was made for the integration of Belgian history within general, European-oriented history instead of being treated separately (Hens, Vanden Borre, \& Wils, 2015). This project for an 'integrated history' would nevertheless only be implemented after the Second World War in an era of changing national memory politics.

That change in memory politics was closely related to the experience of the two World Wars in Belgian society at large. For twice during those wars, a considerable part of the Belgian people collaborated with the German occupier. Particularly in the Flemish part of the country, collaboration was significant. The disregard by the Belgian government of the development of a subnational, regional nationalist Flemish Movement, can partly serve as an explanation here. For a long time, this movement had not been acknowledged, and when it finally was in the first decades of the $20^{\text {th }}$ century, the concessions the government made, were considered too little, too late. (A part of) the Flemish Movement radicalized, and became increasingly anti-Belgian (Witte et al., 2009).

The significant collaboration, particularly in Flemish as well as in catholic circles, led to a fairly widespread consensus after the Second World War that the Belgian educational system, and by extension popular historical culture, had failed to encourage a sense of patriotism and civic duty (Lobbes, 2012b). Education policymakers' initial answer to this conclusion was a plea for a renewed patriotic zeal. From the late 1950s onwards, however, a left-wing group of influential history educators and inspectors in public education proposed a so-called 'planetary' view on history. They demanded that national, Belgian history would not be taught in its own right anymore, yet would be embedded in a more internationalist, even global discourse, in order to reinforce democratic citizenship education instead of patriotism (Lobbes, 2012a). This would lead to gradual changes in history education, culminating in a big educational reform in 1970.

\section{HISTORY VERSUS SOCIETAL EDUCATION IN THE 1960S-90S: CIVIC ORIENTATION TOWARDS DEMOCRATIC PARTICIPATION AND GLOBAL CITIZENSHIP, VIA A HUNT FOR THE WRONG PAST}

During the 1960s, a widespread demand for radical social and cultural reform in schools emerged in general, inspired by the democratization paradigm. This resulted in the establishment, in 1970, of the so-called 'Renewed Secondary Education'. This introduced a series of structural and pedagogical innovations, such as a common core curriculum, new evaluation techniques, teaching methods, subjects, and interdisciplinarity. No longer the subject matter or the teacher were at the center of education, but the student. Furthermore, it was claimed that all students ought to have access to and participate in present day's democracy. Education therefore strongly concentrated on explaining contemporary society (Lobbes, 2012b). From that point of view, the position of history education came under attack. According to critics, history lessons were antiquated and of little social or civic use. Furthermore, the school subject history was insufficiently oriented 
towards global history. A plea was made to replace history education by a new subject of 'societal education'. In order to defend the position of their school subject, history inspectors stressed the importance of current questions of human rights, social justice, emancipation and democracy.

After long and fierce debates a compromise was reached. History education remained to exist, be it in a reduced form. History itself was stripped of its national framework and was resolutely replaced by a (Western-)European historical framework. This was connected to the fact that the memory of the Second World War in Belgium had become ideologically-charged and communitarian (Rosoux \& van Ypersele, 2012). As a result, also influenced by the growing political visibility of both Flemish and Walloon nationalist movements, the Belgian government choose not to invest in national identity building anymore in history education. Patriotic discourse was replaced by a discourse of attachment to democracy, human rights, tolerance, and solidarity. Within this new paradigm, special attention was paid to the 'dark pages' of the past connected to colonialism, war, prejudice, and social inequality. As learning from and following exempla of great and virtuous men from the past had proven no to be efficient, curriculum developers became increasingly convinced that young people might probably learn better from the 'wrong' past, providing examples not to follow (Lobbes, 2012b; Wils, 2009). Al this led to a very presentist, sometimes even anachronistic approach of history, in which moral judgment prevailed over historical understanding.

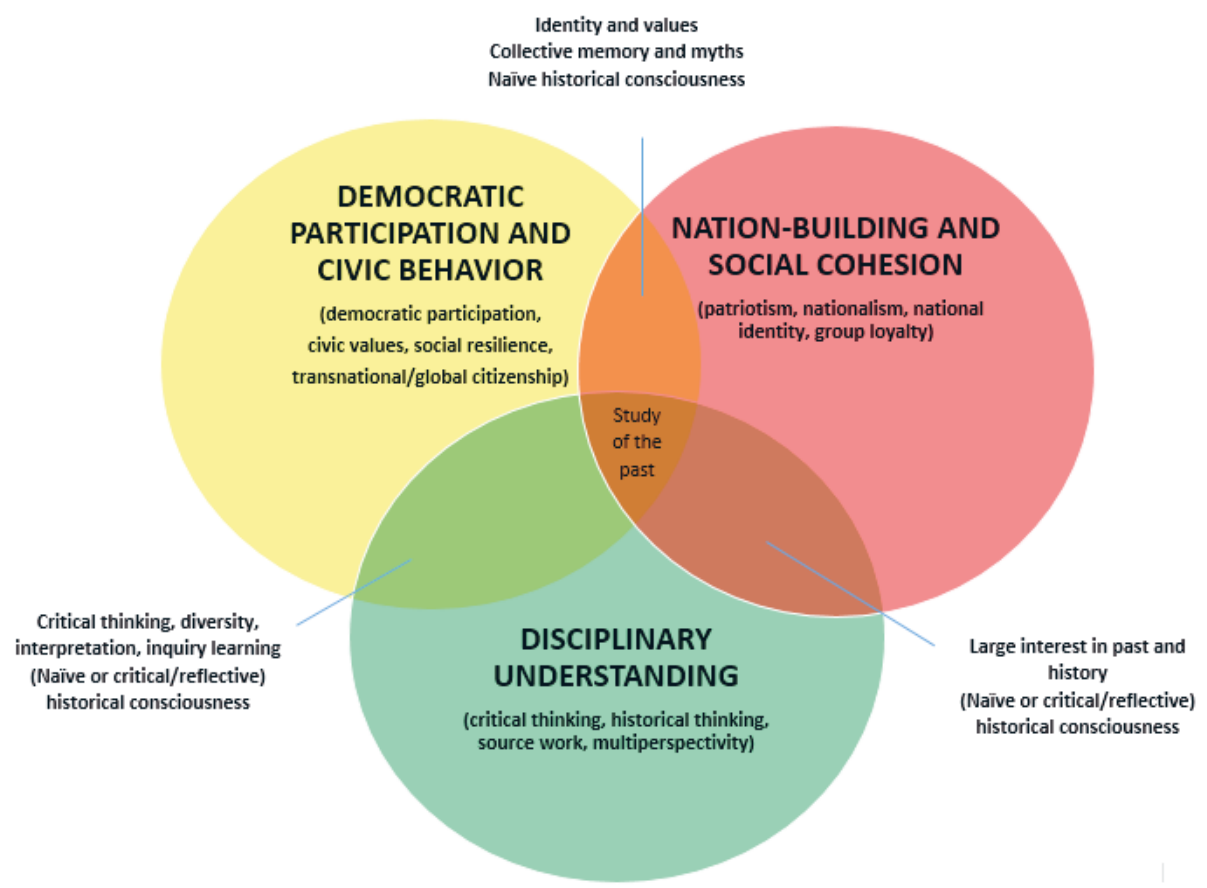

Graph 3: Belgian history education of the 1960s-1990s situated in the three clusters. 
Throughout the 1970s-1990s, this approach of history education was heavily contested. Many academic historians opposed what they considered the 'dictatorship of the present'. In their opinion, the past should be approached in its own right and logic. They also criticized the way 'historical inquiry' was established in history education. They called it 'fake' inquiry learning, since the outcomes of the inquiry, emphasizing the value of Enlightened civic behavior, were always fixed on beforehand (Lobbes, 2012b). Several history teachers also resisted, because the presentist approach hindered the construction of a historical frame of reference and a true understanding of the past.

And what about the students? How did they receive history education oriented like this? And how effective and efficient was history education in transmitting moral, civic values to them? Evidence can be found in two large-scale surveys conducted in Flanders, in the mid-1990s.

A European project, entitled Youth and History, asked 32,000 young people from 27 European countries about their historical interest, their political attitudes, their attachment to human and civil rights, and their perception and appreciation of the school subject history. In Flanders in 1995, 577 students from the 10 $10^{\text {th }}$ grade participated. Results revealed that Flemish students did not show much interest in the school subject of history. On the question "What does history mean to you?", many answered "a school subject and no more" and/or "something dead and gone, which has nothing to do with my present life". Furthermore, Flemish young people on average did not really testify to an attachment to global citizenship. The average Flemish student was for instance, compared to the participants of 26 other countries, the least inclined to give voting rights to immigrants. Moreover, and despite the emphasis in Flemish history education on the 'wrong' colonial past and neocolonial attitudes, the average Flemish student was, after the Czech student, also the least disposed to agree with the statement that "Europe is a group of white, rich countries guilty of economic and ecological exploitation of the rest of the world". Not only did Flemish students apparently not adopt moral lessons from the colonial past, they also rejected second most in general the idea that history can teach us something (Van Dooren, 1996, pp. 370-371).

Many of the findings in the Youth and History survey were confirmed in a large-scale survey conducted in Flanders in 1996, among $47512^{\text {th }}$ grade students (Goegebeur, Simon, De Keyser, van Dooren, \& van Landeghem, 1999). It focused on possible connections between knowledge of and dealing with the past after six years of secondary education, and on attitudes towards contemporary pluralism, political participation and democracy. Results showed that students had little knowledge of (a historical framework of) socio-cultural pluralism and multiculturalism. Furthermore, the researchers concluded that six years of secondary school history education had not led to a decrease of ethnocentrism and an increase of cosmopolitanism, clear-cut tolerance and pluralism. If tolerance, humanism and pluralism already were present in students' minds, it concerned a sense of tolerance with limits and under certain conditions. The presence of foreigners was accepted, but they had to adapt themselves to 'our' culture.

In sum, both surveys seem to clearly indicate that presentist and moral-oriented history education did not cause the desired effects. Both the interest in history and civic attitudes related to an open worldview (distancing from ethnocentrism) fell short of expectations. 


\section{FLEMISH HISTORY EDUCATION FROM THE YEAR 2000 ONWARDS: TESTIFYING TO PARTLY CONTRADICTORY DISCIPLINARY AND CIVIC ASPIRATIONS}

In 1990, secondary education in Belgium faced a new reform, as the introduction of the 'Renewed Secondary Education' had continuously given rise to fierce debates. A 'unified' type of education was installed. This coincided chronologically with the regionalisation of education policy in Belgium. From the 1960s onwards, control over educational policy was increasingly transferred to the three regional 'Communities' of Belgium, who made different choices concerning educational policy. The process was completed in 1989 with the formal handover of all educational matters to the Dutch, the French and (the very small) German Communities (Lobbes \& Wils, in press). From this point onwards, the focus will be on Flemish education.

A new secondary education curriculum was set up by the Flemish government, in which the compulsory nature of history was guaranteed. Final objectives, or standards, were formulated, delineating the minimum targets school subjects should meet. History standards were established in 2000; they are still in use today. The standards set two main aims for history education. On the one hand, the standards approach the school subject as an introduction to history as a scientific discipline, in which the past can be discerned after an extensive learning process of source criticism. On the other hand, history education is expected to help prepare young people to become good and responsible citizens, and is ascribed four functions with regard to 'pupils as members of society':

- to develop 'historical consciousness' (i.e. "the establishment of relationships between past and present and [...] the opening up of lines of thinking in the direction of the future"),

- to offer cultural training (with a special focus on "the way in which people from European and non-European societies perceived their reality and on the basis of their perception of that reality shaped it further"),

- to offer training in 'social resilience' (the critical handling of information),

- and to stimulate 'identity building' (Flemish Ministry of Education and Training, 2000). The standards state that history education should support young people in their search for both personal and social identities, emphasising the plural character of identity. They do not refer to, nor try to support, a (sub)national identity.

The main frame of reference is, by contrast, Western (and especially Western European). Belgian (or Flemish) history is hardly referred to (Van Nieuwenhuyse \& Wils, 2015). The values the history standards promote are also Western oriented. Democracy, critical citizenship, human rights and Enlightenment values such as freedom and equality underpin the history standards. Despite their Western orientation, the standards do explicitly encourage students to try to frame historical phenomena in a broader, worldwide context, i.e. through the requirement to address at least one non-Western society per stage. This choice reflects the ambition to take into account the growing impact of supranational political structures, globalization and intercontinental migration. At the same time, however, it reaffirms the Western orientation of the history curriculum, suggesting that the most important part of history is to be found in the historical trajectory of Europe and the Western World. By studying non-Western societies in a separate manner, it seems as if 'they' (those societies) can be considered completely unrelated to 'us', and hence fall outside of the 'regular' history (Van Nieuwenhuyse \& Wils, 2015). In that sense, the curriculum 
constitutes a new articulation of the old division between 'the West and The Rest' (Hall, 1992).

In defining the standards, the Flemish Community made a deliberate choice not to enumerate factual knowledge that must be taught; they primarily put critical-thinking skills and attitudes to the fore, in order to connect to the academic discipline of history. In so doing, however, they burden history teachers with partly contradictory expectations, particularly regarding the position of the present. On the one hand, the standards expect teachers to learn their students, in line with the academic history discipline, to place historical facts in their historical context and detach themselves from the present. On the other hand, however, history education is expected to look at the past on the basis of a concern for contemporary social problems; students should testify to a historical consciousness and learn lessons from the past that are relevant for the present and the future (Van Nieuwenhuyse \& Wils, 2012). This creates a field of tension.

Furthermore, the standards approach history mostly in a 'realist way' suggesting the past can be fully and unambiguously known; in so doing, they adhere to an outmoded neomodern disciplinary approach. The constructed and interpretative character of history-the postmodern approach, currently prevailing in academia-is only implicitly touched upon. Reasoning about sources for instance-the critical assessment of the value of information, and the usefulness and limits of the source, recognizing the author's perspective and analyzing what sources do, while taking into account the context in which the source was produced (Van Nieuwenhuyse, Roose, Depaepe, Verschaffel, \& Wils, 2017)—is almost paid no attention to. In general, the standards do not explicitly address the need for epistemological reflection. They promote constructivist elements especially in terms of studentcentered and student-activating teaching methods rather than in terms of epistemology.

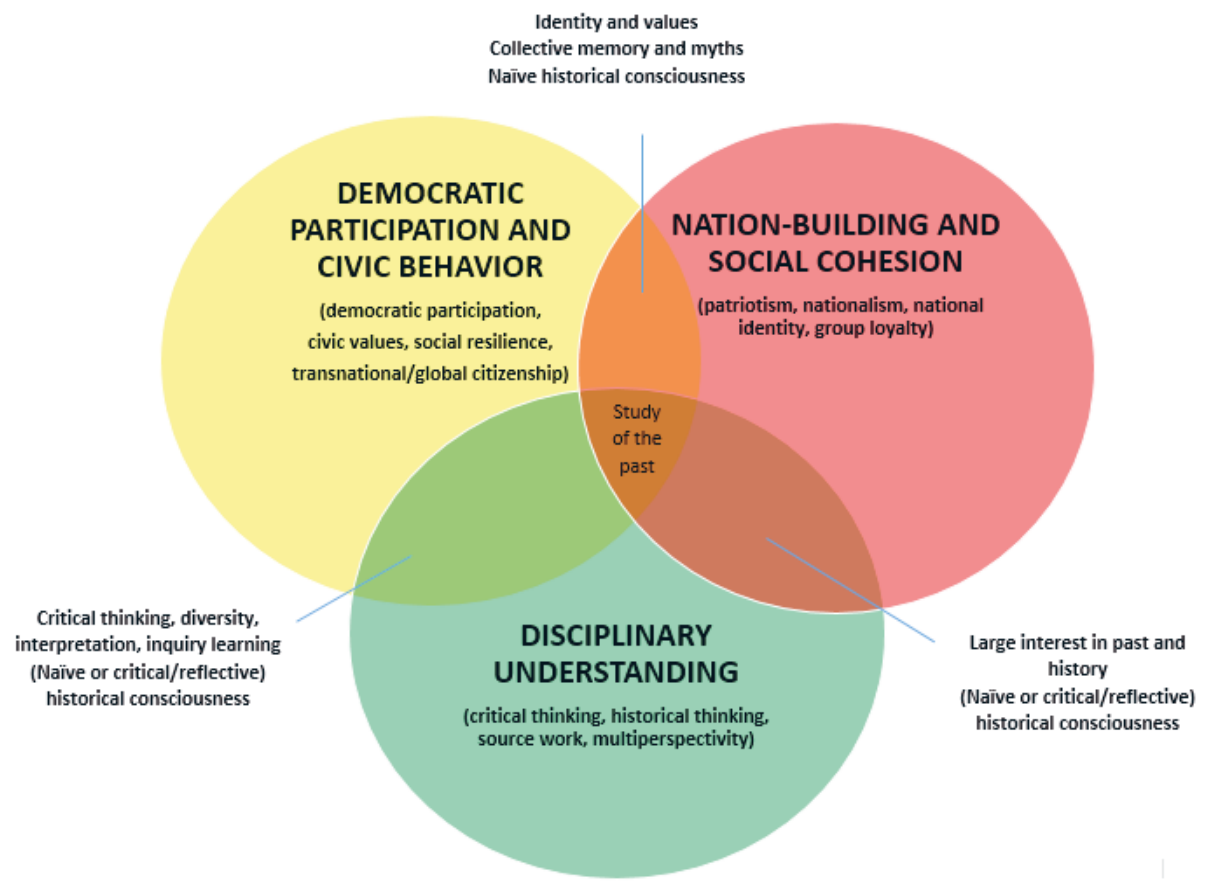


Graph 4: Flemish history education since 2000, situated in the three clusters.

When taking the effects of the combined neo-modern and Eurocentric approach of the past in the history standards into account on teaching practices and on students' thinking and behavior, three problems seem to occur in history education. On the level of understanding the past and of building historical consciousness, Eurocentrism leads young people to a very limited, one-sided and narrow-minded understanding of the past. It creates a heavily biased impression of the (alleged centre) place of Western Europe in global history. It leaves no space for including multiple perspectives, i.e. those of 'the non-Western (European) other', yet by contrast rather excludes 'the other' from history. Furthermore, Eurocentrism brings about a focus only on highlights of European history, while ignoring dark pages from that past that occurred simultaneously. The Renaissance coincided for instance with pre-modern colonialism, and Enlightenment (partly) with modern imperialism.

On the level of understanding history and historiography, several studies reveal that naïve epistemological beliefs of how historical knowledge is constructed, are rather reinforced than changed. Research analyzing written history exams for the $11^{\text {th }}$ and $12^{\text {th }}$ grade shows that the constructed nature of historical knowledge is only rarely touched upon (Van Nieuwenhuyse, Wils, Clarebout, Draye, \& Verschaffel, 2015). ${ }^{1}$ This finding was confirmed in another research, in which 88 secondary classroom history lessons from the $7^{\text {th }}$ till the $12^{\text {th }}$ grade have been observed and analyzed, on how primary sources are dealt with: to provoke reasoning about sources (as explained earlier), or solely to reason with sources, referring to the skills involved in selecting information from sources and using this information to support a claim about the past? Analysis showed that primary sources played an important part in the 88 classroom observations, yet were mainly used primary sources to build content-related knowledge of the past, via comprehensive reading. Epistemological reflection about the interpretive and constructed nature of historical knowledge was only rarely fostered (Van Nieuwenhuyse et al., 2017). In so doing, students might start to consider sources as exact mirrors of the past, instead of as subjective representations that need to be critically assessed.

Both previous remarks clearly show that history education hence does not meet the standards' expectation of introducing young people to the academic discipline of history. The neo-modern and Eurocentric approach of the past simultaneously also hinders the civic aspirations of history education. The (most often only content-related) way sources are dealt with does not encourage the critical handling of information, and hence does not sufficiently train young people in 'social resilience' (Van Nieuwenhuyse et al., 2017).

The heavily biased representation of Western Europe in global history and the absence of non-Western European perspectives and voices have important implications for students' historical consciousness and for their identity construction. Research shows that the Eurocentric suggestion that Western Europe always was in the center of human civilization, gives rise to feelings of superiority. At least some young people in Flanders, belonging to the white majority group, get the idea that 'their' culture was and still is superior to any other culture. In a small-scale, qualitative research in which first year undergraduate university students were asked to describe their identifications and to narrate the national past, the students belonging to the majority group claimed to be

\footnotetext{
$\bullet \cdot \cdots \cdot \bullet \dot{*}$

In Flanders, there are no central or national exams. Every teacher designs his or her own exams, sometimes in consultation with the history colleagues of the same grade and/or track, and in accordance with the prevailing standards.
} 
open-minded European or global citizens, yet in constructing a European human rights narrative, they built in new forms of inclusion and exclusion. They claimed, for instance, to embrace an open society in which all migrants are welcome on condition that 'they' accept 'our' values. The 'open' society to which they referred does hence not appear to be that open. Some students even judged other cultures and societies according to their progressive human rights narrative. One student, for example, compared the long path to freedom, equality, and democracy in Belgium and Europe with the present-day Arab world. Reflecting the 'regime of truth' of 'the West and the Rest' (Hall, 1992), he concluded that "they still consider religion there to be very important; we here have gained much more freedom" (Van Nieuwenhuyse \& Wils, 2015, p. 61). He hence unintentionally drew new boundaries between the 'progressive' and 'free' West and the 'regressive' Arabic world. The Eurocentric approach also impacts the thoughts and sense of belonging of students from ethno-cultural and national minority groups. In that same small-scale qualitative research, a student from Polish descent indicated she did not testify to any sense of belonging regarding Belgium and its past. As she did not feel herself and her history acknowledged, she indicated not to attribute any significance to Belgian history and history education in Flanders in general. A feeling of alienation dominated her mindset (Van Nieuwenhuyse \& Wils, 2015). Eurocentric history education, in other words, can easily lead to an us-versus-them stance and to an exclusive and excluding social identitybuilding process, leading young people from the majority group to feelings of superiority, while young people from minority groups feel alienated.

\section{CLOSING REMARKS: A LOOK INTO THE FUTURE OF HISTORY EDUCATION IN FLANDERS-A TURN TOWARDS FOSTERING HISTORICAL THINKING?}

A retrospective of almost 200 years of history education in Belgium (Flanders) clearly reveals that the school subject was attributed different aims at different points in time. Each of those aims caused different effects, allowing us, in the present, to reflect on and question the significance, feasibility and desirability of those specific main goals.

The analysis showed that instigating patriotism through history education did not work out well in the past. It is also highly questionable if patriotism can still serve as a goal for present-day history education, particularly in a Flemish-Belgian multicultural context, in which different regional, national, ethno-cultural, supranational and global identities simultaneously occur. Which identity should be propagated then? And what about those feeling indifferent to the nation (Zahra, 2010)? Furthermore, it is obvious, as much research shows, that the past is often (mis)used in processes of identity construction (Carretero, 2011). The question then arises where students learn about this issue? In this respect, should it be not first and foremost the task of history education in this multicultural $21^{\text {st }}$ century, to critically deconstruct identity-building processes, rather than fostering or reinforcing one specific identity?

Fostering democratic participation and civic behavior was not that successful either, probably particularly because of the hypodermic needle-like approach. Constructivist and socio-constructivist theories have clearly shown for several decades now, that students do not simply adopt what is served them up. They are no passive receptors, yet actively attribute significance and search for meaning themselves. The question then arises if, in 
this $21^{\text {st }}$ century in which we aim to emancipate young people, it is not wiser to teach rather than to preach? Does it not seem far more important to teach young people how to think, and to enable them to think critically, rather than to teach them what to think?

And what about the aim of initiating historical consciousness among young people? The notion of 'historical consciousness' is not first and foremost about understanding the past and history, yet can be defined as the connection between interpretations people make of the past, their perceptions of the present and their expectations for the future. The concept refers to an individual, mental structure that includes a number of specifically historical (consciousness of time, historicity and reality) and a number of social dimensions (identity, group and political awareness and moral consciousness) (Pandel, 1991). The ambition to connect past, present and future in one concept has, however, problematic sides. Young people, for instance, often develop opinions about present and future, based on non-historical categories, such as pride, optimism, or bond with religion. Moreover, young people often judge past events based on present-day societal, moral and personal opinions, thereby completely ignoring historical contexts. They approach the past in a very presentist and even anachronistic way. In so doing, they build hence a very biased understanding of the past, leading to a distorted historical consciousness (Van Nieuwenhuyse \& Wils, 2012; Von Borries, 1994). The question then arises if it would not be advisable to orient history education particularly towards a detached, critical and reflective study of the past and of history? Should history education be immediately connected to one's own life and serve as a book of recipes for the future, or should it be first and foremost be about studying, understanding and critically deconstructing (historical representations of) the past?

Here, historical thinking comes to the fore, as it aims at understanding both the past and how knowledge of the past is constructed. It goes beyond a Eurocentric view of the past, since it always takes multiple perspectives into account, and hence includes sources and perspectives of 'the non-(Western-)European other'. Furthermore, from the awareness of the difficult relationship between past and present, historical thinking problematizes the connection between past, present and future, and aims to critically deconstruct historical narratives and (mis)uses of the past in collective memory, in current political and societal discourses and in identity-building processes. School history, as mentioned earlier, is the sole place where all young people can learn the very important competence, certainly in this so-called post-truth age of fake news, to think historically. In so doing, history education not only fosters a better historical understanding of past and history; it can equally contribute to civic attitudes as it demands respect for facts and evidence, and helps in keeping debates fair and clear and in busting myths. It fosters emancipation as it emphasizes agency, since it involves the very understanding that the present is not merely determined by the past, yet, by contrast, is malleable and changeable, which encourages civic engagement. Finally, historical thinking shows students that human beings are historical, time-bound beings with changeable value patterns (Harris, 2011). This encourages students to go into dialogue with other value systems and cultures, in an open-minded way, and to reflect on the notion of 'common humanity' (Stuurman, 2017). In so doing, historical thinking equally allows space to bring in emotions in the history classroom. It acknowledges and provides the opportunity to discuss emotions (Epstein \& Peck, 2018). 


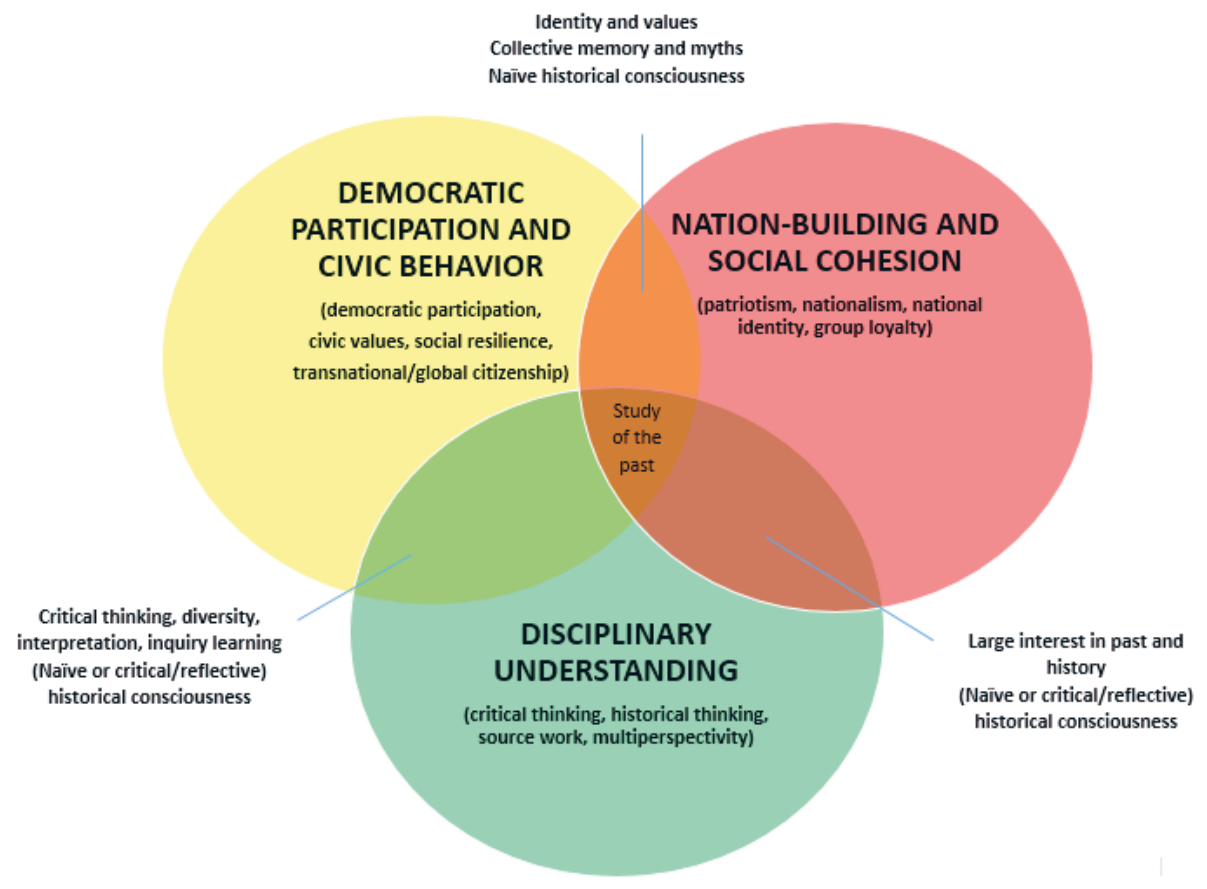

Graph 5: Flemish history education in the future?

In Flanders, at present, a reform of secondary education is taking place. For the subject of history, attempts are made to set historical thinking as the main goal. This concept is defined as follows:

Historical thinking is first and foremost about understanding and organizing information about the past, with the aim of describing, comparing and explaining historical phenomena (people, groups, events and developments from the past) in their historical context and in a long-term. It is important, in this respect, to understand that past and present are fundamentally different. Therefore, historical thinking is also about an understanding of and a reflection on the complex relationship between past, present and future. This can, among others, be done by drawing analogies between the past and the present, in search for similarities and differences. Historical thinking hence requires an understanding of both the past and historical practice, which are inextricably bound up with each other. For one needs to know how knowledge of the past is constructed, and one needs to understand the tentative character of historical knowledge. Only then, one can start thinking critically of (representations and uses of) the past." (Van Nieuwenhuyse, 2017, pp. 265-266)

The operationalization of historical thinking involves five subcomponents. Historical thinking starts with asking questions about or including the past. Subsequently, such historical questions are situated in a broader historical context (instigating a historical frame of reference), and historical sources are searched for and selected that can help to formulate an answer to those questions. Bases on critical source analysis, and applying typical historical reasoning, a substantiated answer is given. All this is expected to ultimately lead to what could be called 'historically conscious behavior'. This operationalization can be visualized as follows: 


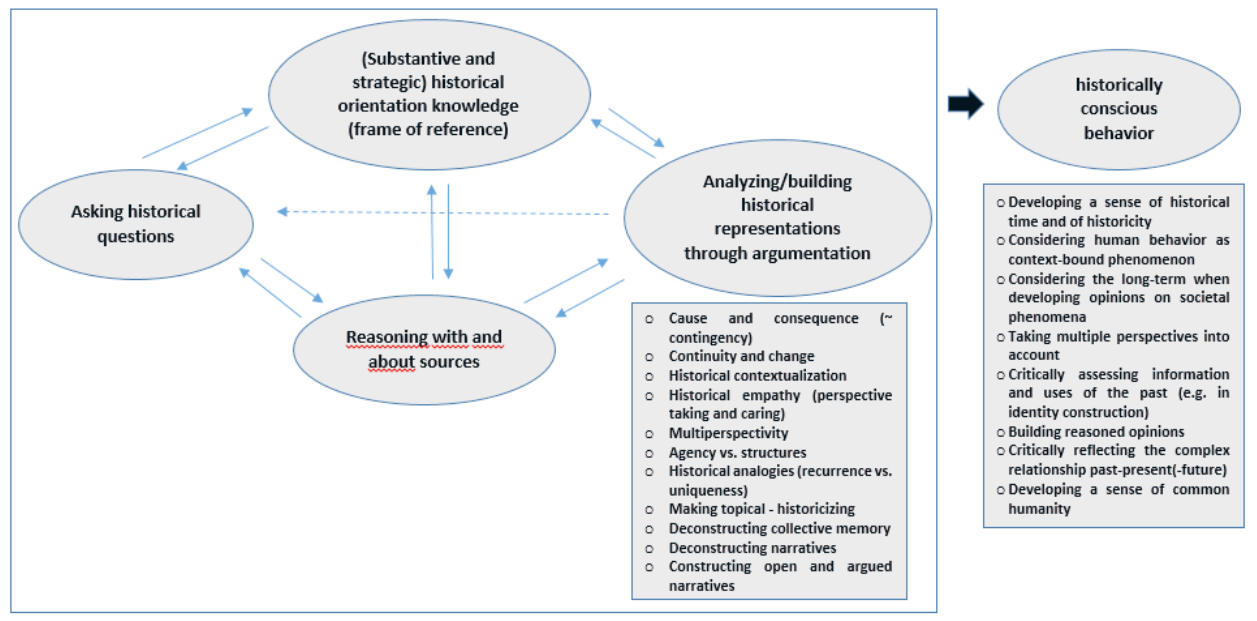

Graph 6: An operationalization of historical thinking.

Towards setting historical thinking as the main goal for history education as well, however, a critical stance should be taken. Several questions arise in this respect. First, as this thinking is generally considered an unnatural act: is it feasible to bring students to historical thinking? And if so, how can this be achieved? What are fruitful educational strategies to develop students' historical thinking? Which teaching methods and skills can especially contribute to that development? Further research in this respect needs to be done. Second, can historical thinking indeed contribute to open-minded civic attitudes? While there are good reasons to assume it actually can, robust empirically grounded evidence for this claim does at present not exist. The proof of the 'historical thinking' pudding will hence need to be in the eating.

\section{BIBLIOGRAPHY}

Angvik, M., \& Von Borries, B. (Eds.). (1997). Youth and history: A comparative European survey on historical consciousness and political attitudes among adolescents. Hamburg: Körber-Stiftung.

Arthur, J., Davies, I., Wrenn, A., Haydn, T., \& Kerr, D. (2001). Citizenship through secondary history. London: Routledge. https://doi.org/10.4324/9780203451632

Carretero, M. (2011). Constructing patriotism: Teaching history and memories in global worlds. Charlotte, NC: IAP.

Epstein, T., \& Peck, C. (2018). Introduction. In T. Epstein \& C. Peck (Eds.), Teaching and learning difficult histories in international contexts: A critical sociocultural approach (pp. 1-13). New York, NY: Routledge.

Flemish Ministry of Education and Training. (2000). Secundair onderwijs, derde graad ASO: Uitgangspunten bij de vakgebonden eindtermen geschiedenis. Brussels: Flemish Ministry. 
Goegebeur, W. (Ed.), Simon, F., De Keyser, R., van Dooren, J., \& van Landeghem, P. (1999). Historisch besef: Hoe waarden-vol?! Ontwikkeling van een analyse-instrument. Brussel: VUBPress.

Hall, S. (1992). The West and the rest: Discourse and power. In S. Hall \& B. Gieben (Eds.), Formations of modernity (pp. 185-227). Cambridge: Polity Press-Blackwell-Open University.

Harris, R. (2011). Citizenship and history: Uncomfortable bedfellows. In I. Davies (Ed.), Debates in history teaching (pp. 186-196). New York, NY: Routledge.

Hens, T., Vanden Borre, S., \& Wils, K. (2015). Oorlog in tijden van vrede: De Eerste Wereldoorlog in de klas, 1919-1940. Pelckmans: Kalmthout.

Lobbes, T. (2012a). Geschiedenisonderwijs tegen de horizon van het heden: Het experiment van Leopold Flam in het Nederlandstalige rijksonderwijs (1955-1970). Belgisch Tijdschrift voor Nieuwste Geschiedenis, 42(1), 139-192.

Lobbes, T. (2012b). Verleden zonder stof. De gedaanten van het heden in het Belgische geschiedenisonderwijs (1945-1989) (Unpublished doctoral dissertation). University of Leuven, Belgium.

Lobbes, T., \& Wils, K. (in press). National history education in search of an object: The absence of history wars in Belgian schools. In L. Cajani, S. Lässig, \& M. Repoussi (Eds.), History education under fire: An international handbook. Göttingen: Vandenhoeck \& Ruprecht.

Pandel, H.-J. (1991). Geschichtlichkeit und Gesellschaftlichkeit im Geschichtsbewusstsein: Zusammenfassendes Resumee empirischer Untersuchungen. In B. Von Borries, H.-J. Pandel, \& J. Rüsen (Eds.), Geschichtsbewusstsein empirisch (pp. 1-23). Freiburg: Centaurus.

Rosoux, V., \& van Ypersele, L. (2012). The Belgian national past: Between commemoration and silence. Memory Studies, 5(1), 45-57. https://doi.org/10.1177/1750698011424030

Seixas, P. (2017). Historical consciousness and historical thinking. In M. Carretero, S. Berger, \& M. Grever (Eds.), Palgrave handbook of research in historical culture and education (pp. 59-72). London: Palgrave Macmillan. https://doi.org/10.1057/978-1-13752908-4_3

Seixas, P., \& Morton, T. (2013). The big six historical thinking concepts. Toronto: Nelson Education.

Stuurman, S. (2017). The invention of humanity: Equality and cultural difference in world history. Cambridge, MA: Harvard University Press. https://doi.org/10.4159/9780674977501

Van Dooren, W. (1996). Not much fun in the Flemish history lessons. In M. Angvik \& B. Von Borries (Eds.), Youth and history: A comparative European survey on historical consciousness and political attitudes among adolescents (pp. 369-376). Hamburg: Körber-Stiftung.

Van Nieuwenhuyse, K. (2017). Knowing \& doing history? De spanning in aandacht voor historische kennis 'versus' kennisconstructie door historici. Tijdschrift voor Geschiedenis, 130(2), 265-268. https://doi.org/10.5117/TVGESCH2017.2.NIEU

Van Nieuwenhuyse, K., Roose, H., Depaepe, F., Verschaffel, L., \& Wils, K. (2017). Reasoning with and/or about sources? The use of primary sources in Flemish secondary school history education. Historical Encounters, 4(2), 48-70.

Van Nieuwenhuyse, K., \& Wils, K. (2012). Remembrance education between history teaching and citizenship education. Citizenship Teaching and Learning, 7(2), 157-171. https://doi.org/10.1386/ctl.7.2.157_1 
Van Nieuwenhuyse, K., \& Wils, K. (2015). Historical narratives and national identities: A qualitative study of young adults in Flanders. Belgisch Tijdschrift voor Nieuwste Geschiedenis. Journal of Belgian History, 45(4), 40-72.

Van Nieuwenhuyse, K., Wils, K., Clarebout, G., Draye, G., \& Verschaffel, L. (2015). Making the constructed nature of history visible: Flemish secondary history education through the lens of written exams. In A. Chapman \& A. Wilschut (Eds.), Joined-up history: New directions in history education research (pp. 231-253). Charlotte, NC: IAP.

Von Borries, B. (1994). (Re-)Constructing history and moral judgment: On relationships between interpretations of the past and perceptions of the present. In M. Carretero \& J. F. Voss (Eds.), Cognitive and instructional processes in history and social sciences (pp. 339-355). Hillsdale, NJ: Erlbaum.

Wils, K. (2009). The evaporated canon and the overvalued source: History education in Belgium: An historical perspective. In L. Symcox \& A. Wilschut (Eds.), National history standards: The problem of the canon and the future of teaching history (pp. 15-31). Charlotte, NC: IAP.

Wineburg, S. (2001). Historical thinking and other unnatural acts: Charting the future of teaching the past. Philadelphia, PA: Temple University Press.

Witte, E., Craeybeckx, J., \& Meynen, A. (2009). Political history of Belgium from 1830 onwards. Brussels: Academic and Scientific Publishers.

Zahra, T. (2010). Imagined noncommunities: National indifference as a category of analysis. Slavic Review, 69(1), 93-119. https://doi.org/10.1017/S0037677900016715 